\title{
NEOLIBERALISM AND HIGHER EDUCATION IN IRAN: A CRITICAL PERSPECTIVE
}

\author{
Mohammad Hasan Mirzamohammadi \\ Shahed University, Iran \\ E-mail: mir.educated@gmail.com \\ Hamdollah Mohammadi \\ Tehran University, Iran \\ E-mail: H9mohammadi@yahoo.com
}

\begin{abstract}
Present research aims to explore the effects of Neoliberalism on higher education based on the Henry Giroux's artistic view points and to examine the process of commercialization and privatization of higher education in Iran, from the same perspective. Giroux considers market-oriented reforms in higher education as a part of the hegemony of Neoliberalism, which seeks to realize the competitive homo economicus, as the ideal man, through using the new techniques of governmentality. Today market-oriented reforms in higher education are prevalent throughout the world. But what is currently in progress as privatization and commercialization in the higher education of Iran is a pale copy of Neoliberalism's logic which is to justify the profit-oriented view of the knowledge and university. Market-oriented reforms of this type are not compatible with Islamic educational goals and will do much harm to Iranian higher education and will have negative impacts on Iranian universities.
\end{abstract}

Keywords: neoliberalism, Henry Giroux, higher education, Iran.

\section{Introduction}

In recent years Neoliberalism is a ubiquitous term in humanities and social studies that without its sound understanding it would not be possible to understand the daily life in capitalist countries and their affiliates. Today many of common concepts in our lives are only understandable in the context of Neoliberal discourse. Although different definitions are given for Neoliberalism (Rowlands \& Rawolle, 2013), yet all researchers agree that Neoliberalism is one of the most important issues of modern world after 1970s (Hall, 2012). In recent years the impact of Neoliberalism on various aspects of human life, and especially on public and higher education is quite evident. As a result, market oriented reforms have become a common discourse throughout the academic world.

Combining with social and cultural circumstances, Neoliberalism has brought about various forms that share some fundamental principles. Although Neoliberalism first appeared in capitalist nations as a mode of economic Liberalism that rose against the Keynesianism and social Democratic tenet in Liberalism, yet its influences have not confined to economy and caused to globalize the market fundamentalism as the dominant model for other fields. Nowadays we can see the traces of Neoliberalism in public and higher education of many countries worldwide: from Japan to China (Moke \& Lo, 2009; Yonesawa, 2007), Chile to the Brazil and Mexico (Ramos \& Fernandez, 2009; Alcàntara \& et al, 2013), Australia to New Zealand (Olssen and Peters, 2005), and other countries including African nations (Tabulawa et al. 2013), and Middle East (Mukhtar, 2013; Atasoy, 2009). 
PROBLEMS

OF EDUCATION

IN THE $21^{\text {st }}$ CENTURY Vol. 75, No. 5,2017

468

Neoliberalism has tried to redefine various elements of higher education that provoked a wave of criticism. Present research then aims to investigate the impacts of Neoliberalism on higher education with emphasis on Henry Giroux's artistic views and to examine the Neoliberal definition of a university, professor, student and academic management.

The effort will be taken to discuss some issues of higher education in Iran in the light of the study of the Neoliberalism as well. It may be so confusing to speak of the impacts of Neoliberalism in Iran, because after the Islamic revolution of 1979, Iran was always opposed to capitalism and attempted to combat Neoliberalism in political and cultural battlefield. But in a trenchant view, today we witness the hidden effects of the Neoliberalism in Iran and especially in the universities. Today, market-oriented reforms are increasingly accepted as inevitable and necessary reforms of higher education in Iranian national document and policies. For example, in recent years commercialization and privatization, as two important elements of the marketisation, have become important parts of the reform discourse in Iranian higher education (mainly in the theoretical level) and national laws such as the Iranian constitution (article 44) and fourth to sixth National Development Documents support their implementation.

Despite these emphasis on the realization of the marketisation in Iranian national policies, it seems that there are fundamental contradictions between the philosophical and cultural foundations of the marketisation (Neoliberalism) and Islam. The notion of Islam and Neoliberalism from human being, knowledge, power, wealth, society, the aims of the education and so on, are very different and are often opposite to each other. Now at the national perspective, the problem is that in the Iranian national guiding document of higher education what aspects of the marketisation are emphasized and are these market-oriented policies consistent with religious aims listed in these documents? In the international perspective the problem is that whether the market-oriented reforms of the Neoliberalism are the same anywhere and how do the specific cultural conditions make a particular form of the marketisation?

\section{What is Neoliberalism? A Girouxian Perspective}

It is difficult to define Neoliberalism theoretically (Saad-Filho and Johnston, 2005) however, Duménil and Lévy consider Neoliberalism as a new social order that "refers to new rules of functioning of capitalism, which affect the center, the periphery, and the relationship between the two"(2005, p.10). Whereas defining Neoliberalism theoretically researchers face many difficulties, in practice, its definition is easier as a movement in political economy that appeared mainly in 1970s and 1980s with the Reagan-Thatcher political coalition. Neoliberalism in practice is associated with privatization, free trade, de-regulation, Laissez-Faire, and the rise of international corporates and institutions like World Bank and World Trade Organization (Harvey, 2005). Turner (2008) goes back into 1930s tracing the signs of Neoliberalism: "The term 'neo-liberalism' was coined in the 1930s by the German economist Alexander Rüstow, to indicate the distinction between the prevailing pro-collectivist liberal ethos and the principles of traditional liberalism" (Turner, 2008, p.4). In this decade Hayek, Mises and the other opponents of Keynesianism and socialist economy held the Mont Pelerin conference for revival of the Ideals of Classic Liberals in free market and individualism.

Neoliberalism in its earliest form emphasized education as an important means for shaping the common sense and legitimating the logic of the free market. Many educational scholars critiqued Neoliberalism from different aspects. Ambrosio (2013) classified educational critical researches in the field of Neoliberalism into two major trends: the first, influenced by Anthonio Gramsci (the Italian Neomarxist), accounts Neoliberalism as the hegemony of the dominant ideology of the upper class in capitalist world that employs education for reproducing itself (Apple, 2004, 2001; Torres, 2009, 2013). Neoliberalism constructs a new historical bloc that "is not simply an alliance, or a coalition but a new civilization design"(Torres, 2013, p. 99). 
The second trend, influenced by Michel Foucault (French Post-structuralist), analyses Neoliberalism as a new governmentality that differs in many aspects from traditional governance. Foucault coined the governmentality and biopower (biopolitics) to show how the new technologies of power form the concrete relations in everyday life. Thus, he extends the concept of power to all aspects of life and unlike Marxism and Neomarxism, does not confine power to the state. From this perspective, Neoliberalism is a new political rationality based on subjectification that extends itself, as a mode of life, via education (Lemke, 2001; Davies \& Bansel, 2007; Peters, 2011, Olsen \& Peters, 2005, Rapper, 2015).

These two trends provide rich analysis of neoliberal educational policies and have been able to provoke many counter-hegemonic educational researches and movements; however, both have some theoretical defects. On the one hand, Neomarxism by confining the power to oppressive form and extreme emphasis on Neoliberalism as a form of ideology (as a false consciousness), fails in analyzing the dynamic nature of neoliberalism and its variant forms in different social texture. On the other hand, absence of subject in Foucauldian genealogy, makes Neoliberalism more vague and irresistible. Foucault, in his last lectures sought to genealogy of modern states and as Flew (2012) stated, Foucault had not intended to critique Neoliberalism rather his prime purpose was to show the lack of wise political rationality in Socialism.

These two trends provide two analytical frameworks that can help us in studying the Neoliberal educational policies. Ambrosio (2013) in his analysis of accountability, employs these two analytical frameworks and believes that

Although these analytic traditions are in many ways incommensurable, they can shed light on different aspects of the inquiry. That is, while Foucault's genealogical approach to historical criticism can help us understand how the language, discourse, and practices of neoliberal accountability produce historical truth and certain kinds of subjectivity, Gramsci's political theory, and especially his concept of hegemony, can inform our understanding of how neoliberalism achieved and maintains a dominant position in educational discourse and practice (Ambrosio, 2013, p. 317).

Ambrosio uses these two analytical frameworks alongside without attaching one to the other, but speaking in Lakatosian words, Ambrosio neglects the relation between hard core and protective belt of these theories that makes his analysis eclectic and not an integrative. In other words, to provide an integrative analytical discourse, by synthesizing two different discourses, we first should provide a meta-language and choose an integrative hard core. The second step is to choose methods and theoretical elements compatible with the hard core.

Henry Giroux's efforts have been partly successful (Giroux, 2005, 2010). He has employed some of the Foucauldian elements within the Gramscian framework. Giroux is influenced by Agamben's reading of the biopower and a postmodernist reading of Gramsci, and provides a partly integrative analytical framework for probing Neoliberal educational policies. Present research benefits from Girouxian analytical framework for studying the Neoliberal policies in Higher Education (HE).

Giroux believes that: "as a political economic-cultural project, Neoliberalism functions as a regulative force, political rational, and a mood of governmentality"(Giroux, 2010, p.589). The aim of the Neoliberal regulative forces is "transforming social state to corporative state"(Ibid, 2010, p.589), that primarily aims to intensify economic growth and to claim that: "social justice can never be the aim of successful economic policy"(Oksala, 2013, p. 64). In 1970 s progressive social and redistributing policies of the 1960s gave way to the marketization and privatization of the state, social services and the whole social life, and the transnational corporates became the new heroes of politics and governing.

In Giroux's view, Neoliberalism especially after September $11^{\text {th }}, 2001$ includes militarization and corporate policies that undermine the public spheres as the base of real democracy 
PROBLEMS

OF EDUCATION

IN THE $21^{\text {st }}$ CENTURY Vol. 75 , No. 5, 2017

470

(Giroux, 2005). Neoliberalism defines market freedom and profit making as the essence of democracy. In this new model, democracy is not concerned with poverty, inequalities and social justice, rather its task confined to securing and guarantying competition in the market and to prevent the all state's interventions in economy, because "economy is a game and the essential role of the state is to set the rules and to ensure that they are duly followed, but it must never interfere with the game itself"(Oksala, 2013, p. 65). Under Neoliberalism, security and therefore terrorism become a rampant motto for legitimating militarization and guaranteeing market freedom. In recent years, militarization of public life under Neoliberalism, embracing torture, violence, war and punishing, transforms the political culture to an intolerant, repressive and jingoist culture, and so Neoliberalism "mimics the very terrorism it wishes to eliminate"(Giroux, 2005, p.4).

It seems that Giroux through combining these two approaches (Neomarxism and Foucauldian perspective) in a relatively coherent form, has been able to provide an appropriate analytical perspective for study of the Neoliberalism. This analytical perspective combines the dynamics of the Gramscian and Foucauldian approach and intertwines the abstract political analysis of the Neomarxism with the objective and dynamic realities of the power. Thus, the Girouxian lenses can be used as an appropriate analyzing tool to peruse the governmentality of the Neoliberalism in public and higher education. However, it should be noted that although this approach at analytical level seems relatively coherent, but in positive level it lacks a proper and realistic plan. In other words, this approach is still at critical level and has failed to provide a practical alternative to the Neoliberalism.

\section{Marketisation of HE}

Nowadays universities are in the front line of marketization and privatization of the Neoliberalism and this changes the nature of the universities, their social functions, their educational goals, the social relations within universities, and the process of production and legitimating the knowledge and consequently the power relations (Giroux, 1999). In the new wave of marketization that occurred after 1970s, the purpose is not to establish a closed relation between the university and industries (Ambrosio, 2013), but it caused to change the university itself to a corporation by transforming its logic of action and system of values.

Neoliberalism attempts to spread corporate and marketized model of university as the most prosperous model and a perquisite of the new age. Advocates of marketization believe that:

...this process will turn HE into a more flexible and efficient institution. They claim that the expansion of the market into the lecture hall will provide better value for money and ensure that the university sector will become more efficient and more responsive to the needs of society, the economy, students and parents (Furedi, 2011:1).

Marketization of HE, based on the philosophical foundation of Neoliberalism includes possessive individualism and competitive society, transforms universities from academic institutions to the quasi-market corporations. Oplataka et al. (2013) believe that in quasi-market universities, the state is an invisible regulator. This regulation occurs not by direct intervention of the state, but through sophisticated use of power as biopolitics and via new technologies of power including the discourse of accountability and competition that forces the universities to adapt to the logic of market. Ball (2003) so critiqued these neoliberal educational reforms: 
...crucially it is a misrecognition to see these reform processes as simply a strategy of de-regulation, they are processes of re-regulation. Not the abandonment by the State of its controls but the establishment of a new form of control... In this way, the state also provides a new general mode of less visible regulation, a much more 'hands-off', selfregulating regulation (Ball, 2003, p. 217).

Foskett (2011) believes that universities have always been trying to link to the market via educating workers and managers, but after 1970s Neoliberalism reconfigured the university- market relation. New form of marketization, based on the philosophical view point of the Neoliberal philosophers like Milton Friedman and Friedrich Hayek, tries to base all policies on possessive individualism and the idea of market as the most successful mechanism for social institutions (Hayek, 2010).

This philosophical view point leads to the idea of the market as a spontaneous order, competition as the principle of the evolution of social institutions, and man as ational, selfinterested chooser (Buchanan, 1984; Hayek, 2010). Thus, HE as a market, should also base on the competition and free choice of students as consumers. Universities should provide the most profitable knowledge and degrees for students so that they can compete in the market and earn as much as possible and employ their time and aptitudes for making money. Universities should provide sufficient information about their commodities (knowledge, research, degree, courses, and etc.) for their consumers and prepare the themes for free choice (Brown, 2011).

According to Giroux, marketization of universities in Neoliberalism is an antidemocratic policy linked with militarization and regulation that undermine the ideals of social democracy by redefining the nature of democracy, politics, freedom and sociality. Neoliberal discourse in HE attempts to remove any problem of the social justice and democracy from universities, and thus depoliticizing HE. Depoliticizing the university was a conservative reaction to the 1960s universities that were highly engaged in political and cultural movements (Aronowitz \& Giroux, 1996). Under marketization, universities enter a highly competitive environment governed by the principles of social Darwinism; the fittest survive and the weakest removed. In this brutal area, universities are in a fatal uncertainty and cannot predict their future funds and resources.

New Public Management (NPM) is an important step toward the Marketization of the HE. NPM tries to replace the academic administration with a new form of management based on market-oriented managers and its consequence is "to view all work relations as principal agent hierarchies, thereby redefining the appropriate process in terms of outputs, and where services are viewed in terms of cost and quality" (Olssen \& Peters, 2005, p. 323). New managers consider $\mathrm{HE}$ as a free market based on the consequences of competition. Thus, universities have to compete and their survival depends on their success in attracting rich consumers, diminishing public expenditures, commercialization of the researches, advertisement and cost- cutting plans.

The NPM in HE transforms Universities to flexible, neutral, and entrepreneurial institutions trying to maximize the efficiency and transparency and to diminish the reliance of HE on the governmental budgets. So, under the NPM, government on the one hand releases itself from spending on $\mathrm{HE}$ and on the other hand increases its regulation on $\mathrm{HE}$ via biopolitics, new technologies of power and unequal relations of power present in NPM.

New managerialism is based on entrepreneurial culture and homo economicus anthropological view point, trying to educate man as a self- interested, rational chooser, and utility maximizer. Thus, NPM in a broader sense embodies an anthropological and philosophical point of view and its ultimate purpose is "capitalization of the existence itself" (Davies \& Bansel, 2007, p. 252), and providing human capital for realization of capitalism not only as a mode of economic system, but as a way of life, a worldview, and as a mode of being. 
PROBLEMS

OF EDUCATION

IN THE $21^{\text {st }}$ CENTURY Vol. 75 , No. 5, 2017

472

In Giroux's point of view, Neoliberalism through the discourse of NPM tries to redefine the nature of HE, make it the pioneer of the new corporative and entrepreneurial culture, and thus to empty the universities from any issues about social justice and inequalities in the name of depoliticizing. In the new model of management, efficiency and the logic of cost-benefit are the key to success and the more customers universities can attract and the more practical outcome they come up with, the more they can raise their rank in the league of higher education and will be rather capable of assuring their survival in the capitalistic academic system. Thus, NPM in HE is a part of a wider attempt toward transforming civil society to an economic society, emptied from the issues of social justice that is indifferent to social and other forms of inequalities. In such a way Neoliberalism tries to redefine the nature of society, democracy and the nature of man in accordance with its market logic and values.

Students as consumers are the core of the marketization of higher education. Under Neoliberalism, through commodifying education, universities are transformed to corporations that attempt to provide knowledge, researches, and degrees as commodities and sell them to their customers including students, parents and industries. In the process of marketization, universities like other corporations, have to be costumer-oriented and attempt to attract their customers. Universities (as cultural malls) should provide the best services and also sufficient information about their services and thus create the best condition for free choice of their customers. "Customers are always right", thus universities should atone their customers even by flattering.

From an anthropological point of view, marketization is based on homo economicus model, man is assumed to be a self-interested utility maximizer that deals with other self-interested individuals in everyday life as a competitive process (Read, 2009). "Public choice theory" (PCT) has an important role in applying the homo economicus model in politics and sociology. Buchanan as one of the pioneers of the PCT believes that in politics like in economic, "we commence with individuals as utility maximizer" (Buchanan, 1984, p.14). Thus, under Neoliberalism, a student as homo economicus tries to maximize his/her utility and all his/her conducts are governed by cost/benefit logic. In the market of HE, students try to achieve the most efficacious knowledge and degree that assure their success in the society as a competitive market.

While Neoliberalism maintains that in this process of free choice, any student can choose his/her own way of success regardless of his class, race and sex, but Giroux \& Giroux (2004) believe that in the Neoliberal HE, success of any student relies upon his class and capital. All students have to compete in similar standard tests, while they are not equal in cultural capital and access to resources. Giroux declares that privatization and standardization try to mask the real reasons of educational failures and their relevance to the macroeconomic and political structures.

In corporative universities, professors lose their traditional social position as a symbol of wisdom, and in the new system of values based on cost/ benefit model, they are suppliers of education as a commodity, and they should attempt to attract their consumers (Giroux, 2006). They should be academic entrepreneurs for which they need to be skillful in selling educational commodities including attracting students and parents, providing enough information about their services, performing researches that are beneficial in short time, and being responsible for continual accountability and national standard tests.

In unequal power relations of NPM the "notions of 'professional', 'trustee' or 'fiduciary' are conceived as 'principal/agent relationships" (Olssen \& Peters, 2005, p. 324). Under Neoliberal governmentality, liberal professionalism which is based on "delegation of power" and "autonomy" is substituted by principal-agent relation that is "hierarchical form of authoritatively structured relation" and tries to undermine academic autonomy (Ibid, 2005, p. 324). Thus, under NPM academic relations transform to a managerial form based on continual monitoring and auditing. In such atmosphere, the relation of professor-manager in universities turns to a hierarchical relation that reduces professor's academic autonomy and forces them to adapt 
themselves to market oriented criteria. In this system they will succeed only if their teaching OF EDUCATION
IN THE 21 $1^{\text {st }}$ CENTURY
Vol. 75, No. 5, 2017 and research can be easily converted to salable commodities (Aronowitz \& Giroux, 2000).

In corporative universities, professors have to comply with their customers' desires, students and industries, so as to provide themselves a budget. Therefore, on the one hand they should offer profitable courses for students, and on the other hand they must convince industries even through substituting critical research with flattering and advertising their goods since very often "corporations increasingly dictate the very research they sponsor" (Ibid, 2000, p.332).

In Neoliberal universities, professors are placed in a strictly accountable system through which they are constantly watched and judged; therefore, in this system success is defined as accordance with accountability criteria. In such atmosphere, professors will lose their job security, they are compelled to work in a highly uncertain and comparative circumstance, and their income depends on how they function in accountability process. Ball (2003) believes that in an accountable system...

...there is a high degree of uncertainty and instability. A sense of being constantly judged in different ways, by different means, according to different criteria, through different agents and agencies... We become ontologically insecure: unsure whether we are doing enough, doing the right thing, doing as much as others, or as well as others, constantly looking to improve, to be better, to be excellent (Ball, 2003, p. 221).

In this process, professors have to adapt to the values imposed on them from outside academic administration and in Ball's word, it leads to values schizophrenia:

Here there is a potential 'splitting' between the teachers own judgments about 'good practice' and students 'needs' and the rigors of performance (Ball, 2003, p. 221).

In marketized universities, the curriculum is overshadowed by the logic of cost- benefit. In the process of competition, universities should judge their courses, researches, and curriculums according to their profitability and their ability to attract customers. Corporative universities divide curriculum to salable units and offer them to the students as customers, and students buy and pay for the units according to their profitability. Curriculums and units are flexible towards customers' needs and the social and economic status of the university.

Thus units, researches and courses that have practical value in the market, become more important and "those areas of study that do not translate into substantial profits get marginalized, underfunded, or eliminated" (Aronowitz \& Giroux, 2000: 333). This leads to a ranking of different field of knowledge; upper ranks are for the more profitable fields like engineering and IT that can transform to the technology and money in a short time and the rank of other fields rely on their ability to produce technology and wealth. Application of the logic of the market in the curriculum of HE, with emphasis on technicization and commercialization of knowledge (Connell, 2013), will result to "downsizing the humanities" and marginalizing other critical areas like social studies, philosophy and art (Ibid, 2013, p.333).

Marketization also leads to changes in nature and purpose of academic research. In this new logic of efficiency, the purposes of researches are to make profits including money and technology. Universities that were trying to produce knowledge for improvement of life condition, today "seek to restrict knowledge to extract a commercial benefit from it" (Connell, 2013, p.108).

In summary, important elements of Marketisation can be expressed as follows: 
PROBLEMS

OF EDUCATION

IN THE $21^{\text {st }}$ CENTURY Vol. 75 , No. 5, 2017

474

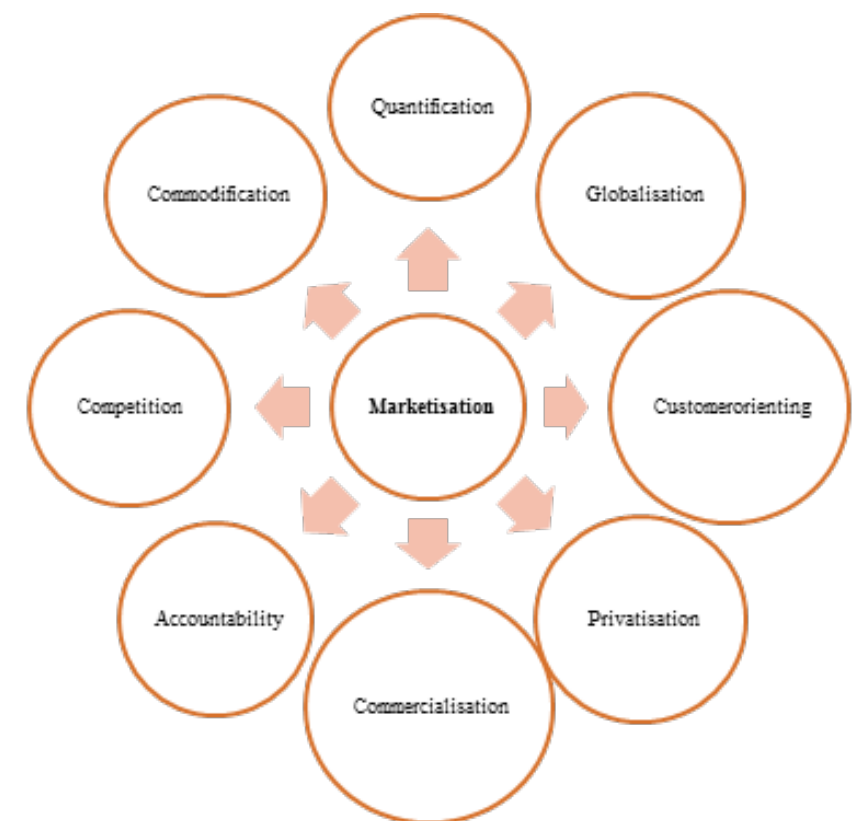

Figure 1: Elements of marketisation.

\section{Marketisation in Iranian HE}

Prior to addressing the impacts of Neoliberalism on the higher education, a brief introduction of higher education of Iran should be outlined. Higher education in traditional sense has a long history in Iran and there were various scientific and research centers in Iran before and after the entrance of the Islam, in which medicine, astronomy, mathematics, chemistry, etc. were taught in high level. The religious institutions for higher education also have a long history in Iran that Howzah is their symbol today. Nevertheless, the entrance of the university in modern sense to Iran took place by Reza Shah in 1934 (Khaki \& Bhat, 2015). University of Tehran was the first Iranian university and a part of the modernization of Iran. From 1934 to the Islamic Revolution, about 26 state-run and private universities were established mainly adopted from American universities.

After Islamic revolution and the formation of the Supreme Council for the Cultural Revolution $^{l}$, it was at first opposed to universities as a symbol of Westernization (in contrast to the Howzah), but after a short time the public universities were licensed again with the aim of Islamicization. In this period, the number of universities was reduced and the license of private universities was canceled (Bagheri \& Karimof, 2013), but after 1983, private universities relicensed in the name of Islamic Azad University and nonprofit institution, after that, the number of public and private universities and institutions in Tehran and other provinces increased rapidly.

According to the Ministry of the Science, Research and Technology of the Iran (MSRTI) (2017), about 4.5 million students are enrolled in 317 public university and state-run institutions, 324 private institutions, 357 branches of the Islamic Azad University, and 500 local branches of the Payame Noor University (public universities mainly for distant learning), Of which $46.1 \%$ are female and $53.9 \%$ are male, $54 \%$ are in public universities and $46 \%$ in private universities and institutions.

1 The council consists of the president, the speaker of the parliament and some individual and legal persons elected by the supreme leader of the Iran. This council was formed after Islamic revolution and its aim is to creating the groundwork for expansion of Islamic culture in the universities. Supreme Council for the Cultural Revolution is the highest institution for decision making in higher and public education of the Iran. 
Since the entrance of the modern university to Iran, higher education has faced some important issues and the Islamicization (attempts to establish humanities based on the Islamic foundation and reform the structures and educational goals accordingly) is their most important. After Islamic revolution, policy makers and specially, Supreme Council for Cultural Revolution tries to islamicize the universities by setting policies and guidance documents based on Islamic principles. Comprehensive Scientific Map (CSM) is the most important guiding document that has been written in recent years, which in one hand tries to make higher education accountable for the needs of the modern world and use it as the basis of the economic and political power, and on the other hand stays committed to the ideals of the religious education. Iranian Supreme Council for Cultural Revolution approved the CSM, as the guiding document for scientific and academic activities, in 2010-2011. This document aims to outline the general direction of the scientific activities in Iran including research, instruction, education and technology according to the ideals of Islamic Revolution and monotheistic worldview (CSM, 2010, p. 1)

In present research the CSM as the most important guiding document of the scientific and academic affairs, is used to analyze the policies and approaches of the higher education in Iran. In the following, the impacts of the Neolibeliasm on different elements of the higher education of Iran will be perused and finally some impacts of the Neoliberalism on higher education of the Iran (at practical level) will be discussed (under the title of the Phantom of Neoliberalism).

In two decades higher education in Iran is also influenced by the process of the Marketisation and the national document like CSM emphasizes the realization of its various dimensions. What lies behind the religious appearance of the CSM is a market-oriented backend seeking to apply the principles of the market oriented management in scientific and academic system. In CSM the target pattern of scientific system is described by market-oriented terms as "supply-oriented and demand-driven" (CSM, 2010, p. 3), that should lead to the realization of the knowledge based economy through market based reforms and commercialization. In this system, the criterion of growth of knowledge is defined based on their profitability in the market: "] the growth [of the biotechnology in order to earn 3\% of the global market. ]The growth [of the Nanotechnology and microtechnology in order to earn $2 \%$ of the global market" (Ibid 2010, p. 8).

CSM attempts to wrap the market oriented reforms in the religious terms as educating ethical and righteous man, but what this document hinges around is converting knowledge to wealth and power and become the dominant scientific and technological power in the Muslim world (Ibid: 6). In this text, we witness signs of marketization and translation of the growth of knowledge to objective output (the number of published articles, the number of registered inventions, and the number of graduates) and created wealth. These signs of market-based reforms can also be seen in other national documents of Iran like the "Fifth Development Plan $(F D P) "$ and "Sixth Development Plan"(SDP). Increased competitiveness in the academic and scientific environments; realization of the entrepreneurial culture; emphasis on skill- oriented goals; realization of the knowledge based economy; privatization; commercialization of the academic researches; and emphasis on the effectiveness as the main criterion to fund research, these are the traces of the market-based reforms in HE of Iran (FDP, 2010; SDP: 2015). The purpose of these plans is to increase the scientific research share of GDP (FDP, 2010: 7) and to direct academic research toward meeting the demands of industries (Ibid, 2010, p. 9).

Other market-based reforms in these national plans are to force governmental universities to charge tuition through admitting students without requesting the national entrance examination scores (Ibid, 2010, p. 14), and also to educate students as competitive human capitals in order to meet the needs of the labor market (Ibid, 2010, p. 17). This would lead universities to an entrepreneurial culture the consequence of which is training the human capital in order to meet the needs of industries and providing skilled workers for competition in the market without paying due attention to the instruction of citizenship skills for empowering the civil society. 
Mohammad Hasan MIRZAMOHAMMADI, Hamdollah MOHAMMADI. Neoliberalism and higher education in Iran: A critical perspective

PROBLEMS

OF EDUCATION

IN THE $21^{\text {st }}$ CENTURY Vol. 75, No. 5, 2017

476

Not only the universities are after training competitive human capitals, but they transform to competitive corporations that have to compete with others in fundraising through selling research or admitting rich students, and as Giroux stated marketization takes away the critical spirit of HE and depoliticizes and depowers the universities.

In an overview, the listed national plans in Iran, emphasize the transformation of HE based on market demands and through managerial strategies (FDP, 2010, p. 7). These strategies include evaluation of academic curriculum and research based on their effectiveness; applying the principles of economic management in universities; establishment of transparent, outputoriented and standard evaluation; and ranking professors and universities in competitive tables. These strategies lead to a kind of neoliberal managerialism which aims to transform universities in accordance with the logic of the free market. Aronowitz and Giroux (1997) believed that such reforms are pathways to revival of Positivism and Neo-Taylorian management with a focus on objectivity and transparency that will result in depoliticization and reproduction of the unequal power relations in the name of standardization and national tests.

In the following table various elements of marketization of Iranian HE have been investigated in the CSM:

Table 1. Marketisation of the HE in CSM (Comprehensive Scientific Map).

\begin{tabular}{|c|c|c|}
\hline Elements & Features & Signs in CSM \\
\hline Commercialization & $\begin{array}{l}\text { Converting academic research and knowl- } \\
\text { edge to power, wealth and technology; linking } \\
\text { university to industry; Science and Technol- } \\
\text { ogy Parks; knowledge-based corporations; } \\
\text { emphasize on the economic returns of the ac- } \\
\text { ademic researches; university as firm and etc. }\end{array}$ & $\begin{array}{l}\text { supply-oriented and demand-driven model in } \\
\text { university(pp. 10-11); knowledge -based so- } \\
\text { ciety (pp.13,31); converting knowledge to the } \\
\text { political power(p. 14); prioritizing the academic } \\
\text { disciplines based on their economic returns and } \\
\text { their contribution in production of the wealth } \\
\text { and power(p. 19); expansion of the knowledge- } \\
\text { based enterprises and creating Over-The- } \\
\text { Counter form them(p. 28); marketisation of the } \\
\text { academic outputs(p. 32); supporting the 'Idea- } \\
\text { to-Market' centers(p. 33); expansion of the Sci- } \\
\text { ence and Technology Parks in science, arts and } \\
\text { humanities(pp. 33, } 57) \text {. }\end{array}$ \\
\hline Commodification & $\begin{array}{l}\text { Converting academic terms and units to sal- } \\
\text { able units; priority of the cost-benefit logic in } \\
\text { educational planning; optimization of the time } \\
\text { to generate more wealth. }\end{array}$ & $\begin{array}{l}\text { Assessing the growth of knowledge by the } \\
\text { growth of the technology and increasing the } \\
\text { GDP (p. 17); increasing the role of the firms in } \\
\text { the educational planning (p. } 40 \text { ). }\end{array}$ \\
\hline Globalization & $\begin{array}{l}\text { Universities entrance in the global competi- } \\
\text { tive free markets; attracting students all over } \\
\text { the world; expansion economic and political } \\
\text { policies for 'structural adjustments' by inter- } \\
\text { national institutions like the World Bank(WB) } \\
\text { and World Trade Organization (WTO); rank- } \\
\text { ing the universities according to their success } \\
\text { in the realization of the qualitive management. }\end{array}$ & $\begin{array}{l}\text { Emphasis on international participation by in- } \\
\text { creasing the number of the international shared } \\
\text { articles; advanced skill training to increase Iran's } \\
\text { share in international markets (p. 32); expansion } \\
\text { of the design and engineering companies for } \\
\text { participating in international projects (p. } 60 \text { ). }\end{array}$ \\
\hline
\end{tabular}


Student as consumer, planning according to the interests of the customers; converting Customer-orienting academic professors-students' relations to economic producer- customer relations; create conditions and providing sufficient information for realization of the for free choice.
PROBLEMS

OF EDUCATION

IN THE $21^{\text {st }}$ CENTURY

Vol. 75, No. 5, 2017
Emphasis on the supply-oriented researches ( $p$. 28); constant monitoring and futurology of the academic and scientific environment according to the demands of the market (p. 35).

Increasing the share of the non-governmental Privatization of the academic services; con- sectors in higher education (p. 26); providing tinuous increase in tuition fees; companies incentive for non-governmental participation in provide loans students to students on condi- higher education (p. 28); increasing the share of tion of a cheap service commitments. the non-governmental institutions in academic researches (p. 42).
Privatization

Standardization; national standard tests; increasing the role of the external controls in assessing the universities; expansion of the New Public Managerialism(NPM); hierarchical power relations in the universities; emphasize on the transparency in the assessments

Emphasis on the realization of the skill-oriented and entrepreneurial culture in academic and scientific environment(p. 26); standardization of the academic and scientific system at the same time preserving the task of the monitoring and planning for the state(p. 27); central governmental planning (p. 28); increasing the autonomy of the universities in providing the financial resources ( $p$. 40); centralized management and validation(p. 40); transparency and quality improvement(p. 42); accountable management (p. 44); standardizing the arbitration proceeding and ranking of the article reviewers (p. 48).

Attain to the first rank among the Islamic univer-

Competition of the universities for attracting students and financial resources; ranking the universities; uncertainty in the academic environment. sities (pp. 14, 41); increasing the competitiveness in the academic era (pp. 32, 41); ranking the knowledge-based enterprises and scientific associations (p. 32); creating ranking system among nongovernmental researchers (p. 42)

Determining the contribution to the technology market as the criterion of the growth of science (p. 15); the number of the articles as the criterion of the scientific growth (p. 16); emphasis on the funding of researches based on their economic outcomes (p. 28); converting the ideas to the products (p. 34); skill oriented training (p. 44).

\section{Conflicts}

From the set of the discussions it can be concluded that in Iran's higher education market-oriented reforms has become an important discourse at theoretical level and policy making. Today the market related concepts such as commercialization, privatization, knowledge-based economy, and so on become the commonplace literature of the politicians and policy makers. In spite of this market-oriented fascination, it seems that Marketisation as a culture is not compatible with Islamic goals such as social justice, truth seeking, virtue, and etc. that emphasized in the national plans. 
PROBLEMS

OF EDUCATION

IN THE $21^{\text {st }}$ CENTURY Vol. 75 , No. 5,2017

478

In Islam the knowledge (Marefat) has been described with the criterion of the truthseeking, religious worldview, and the guidance to the human happiness (CSM, 2010, pp. 9, 30), and the commoditized knowledge of Neoliberalism not only doesn't fulfill these criterion, but also hinders their realization. Under the neoliberalism knowledge transform a saleable commodity and profitability become the dominant criterion of the validation. This commodification transforms the nature of the knowledge and turns it into a handful of the superficial information that is alien to the knower. Thus, in the process of the Marketisation not only does knowledge loses its critical and emancipatory nature, but itself becomes a big issue for humanity.

In the process of the market-oriented validation of the academic disciplines, early-return sciences like nanotechnology, IT, and so on will be the highest priority and on the contrary, the humanities and philosophy downsizing, because they are not able to meet the competitive criteria of the market. The CSM repeatedly emphasized on the revival of the Islamic-Iranian civilization through the growth of the political power and technology (Ibid, 2010, pp. 37, 54). While the political power, wealth and technology have important role in the formation of the civilization, but one should not ignore the role of the humanities.

Another conflict of the Marketisation with Islamic educational aims is the contradiction between the homo economicus model and Islamic man. The Islamic model of man as the aim of the public and higher education so depicted in CSM: dignity, truth seeking, wise and noble (Ibid, 2010, p.9). But what is resulted in marketized universities is self-interest, utility maximizer, competitive and rational man; this model not only is not compatible with the Islamic criteria, but also as a secular model of man is against it. Thus, marketisation in anthropological level is an important issue in realization of the Islamic educational goals. While in Islam competition, wealth making, self-interesting and utility making will not be blamed on their own, but when these characteristics assumed as the nature of the man, they become threatened. In other words, wealth making, competition and so on are the instruments that must serve the transcendental characteristics of man. Some of the conflicts of the marketisation and Islamic educational goals (expressed in the CSM) are summarized in the table below:

Table 2. The conflicts.

\begin{tabular}{ll}
\hline Marketisation & Islamic Educational Goals \\
\hline Privatization and competition (cause to inequality) & Emphasis on the social justice as the main goal \\
\hline $\begin{array}{l}\text { Student- professors' relations transform to customer - } \\
\text { producer relation }\end{array}$ & $\begin{array}{l}\text { Emphasis on the intrinsic value of the teaching and the } \\
\text { moral superiority of the professors and teacher }\end{array}$ \\
\hline $\begin{array}{l}\text { Expansion of the consumerism in the theory and action } \\
\text { Reducing the autonomy of university professors in the } \\
\text { process of New Public Management and coercive account- } \\
\text { ability }\end{array}$ & $\begin{array}{l}\text { Opposition to the consumerism as the cultural invasion of } \\
\text { the capitalism }\end{array}$ \\
\hline $\begin{array}{l}\text { Educating atomic, self-interested and competitive entre- } \\
\text { thersity professors }\end{array}$ & $\begin{array}{l}\text { Strengthening the culture of the cooperation and respon- } \\
\text { sibility in scientific and academic era and realization of } \\
\text { the educated, elite and good man }\end{array}$ \\
\hline $\begin{array}{l}\text { Instrumental vale of Knowledge as commodity } \\
\text { pocial Darwinism, cold and wild competition, possessive }\end{array}$ & $\begin{array}{l}\text { Emphinsic value of knowledge } \\
\text { interests }\end{array}$ \\
\hline
\end{tabular}




\section{The Phantom of the Neoliberalism}

In the previous sections the marketisation of Iranian higher education in the theoretical aspect was studied and some of the challenges were examined. Here some practical challenges of the marketisation in the Iranian higher education will be perused. Today HE in Iran faces unique problems and while Neoliberalism should not be blamed for all of these problems, yet it has further complicated some of these problems by providing theoretical justification for them. In recent years HE in Iran on the one hand, has experienced an anomalous increase in the number of students (from 175,672 in 1978 to 4,802,721 in 2015), and on the other hand the state budget cuts, lack of qualified professors and academic facilities have reduced the efficiency of higher education (MSRTI, 2017).

Under the pretext of lack of state budget, in recent years, privatization has become one of the main reforms in HE of Iran. In 2017 about 46\% of students have been studying in private universities including Islamic Azad University (IAU) and other Nonprofit Universities. (Ibid, ${ }^{2017}$ ). Of course, it should be noted that some of the public universities (like Payame Noor University, International Branches and Distance Learning) are also charging tuition, taking these cases into account, a high percentage of Iranian students are paying tuition. According to Stone (2016), "Since 1979, the government has opened scores of universities, among them IAU and Payame Noor University, both of which have hundreds of branches across the country". These branches admit thousands of students each year and graduate them without having conformed to academic standards. In spite of the poor instructions and academic conditions, the tuitions in these private higher education institutions have increased anywhere between 15$25 \%$ annually. Furthermore, the International Branches ${ }^{2}$ of public universities have a similar condition ${ }^{3}$.

Thus, in recent years the number of the nongovernmental universities and their admission of students are on the rise and a significant percentage of students are paying tuitions, however they are facing a shortage of qualified professors and educational facilities that leads to a poor quality of education. Thus, in the name of privatization, the number of low quality HE institutions across the country has increased greatly, the main purpose of which is gaining profit in the name of higher education and through converting knowledge and degree into a salable commodity. Even well-known public universities (such as University of Tehran, Tarbiat Modares University and the like) have to offer some monetary courses (like Distance Learning), for funding. For justification of this kind of privatization, some proponents pose neoliberal arguments as free choice and reducing the governmental interference in HE, but what we witness in HE of Iran, is a mere phantom of Neoliberalism; a kind of privatization and commercialization that will run irreparable risks to the scientific and academic development which neither reads with the basic religious principles for education of wise man nor is in its accord with the principle that considers knowledge as a way to understanding the reality.

This phantom, has had other devastating impacts on HE in Iran and on its relation to industry. Market- oriented reforms aim to reduce universities to corporations whose main purpose is to produce and sell knowledge, courses and degrees. The Science and Technology Parks is a model for corporate universities that their main purpose is to transform knowledge to salable commodities. In recent years national documents in Iran have emphasized on the expansion of Science and Technology Parks not only for science, but also for Humanities and Arts (CSM, 2010, p. 52), and therefore their attempts will reduce higher education to an economic activity.

Another effect of this phantom has to do with academic evaluation. In recent years in the academic evaluations the objective outputs like the number of articles has become an important 2 Branches of public universities like University of Tehran that under international label, charge tuition. 3 for example, the annual tuition fee for Ph.D. program in Management at the International Campus- Kish Island of University of Tehran is about 8200 USD per year: (http://kish.ut.ac.ir/IPPWebV1C010/English_WebUI/Templates/WebSiteTemplate1/WebSiteFile90996.aspx) 
PROBLEMS

OF EDUCATION

IN THE $21^{\text {st }}$ CENTURY Vol. 75 , No. 5, 2017

480

criterion and it has created a condition that Stone (2016) calls it "shady market in scientific papers" in Iran. Lack of a proper monitoring system in evaluating the scientific activities and researches; poor quality of many private and public universities; and the state negligence of these issues lead many students and even professors to sell and buy theses and articles. Today, hundreds of companies freely buy and sell articles and theses in Iran and government or judicial bodies have not taken any preventive measures. These companies are advertising their commodities in the vicinity of public and private universities and in the cyber space and have a large number of clients especially from private and AIU universities. This has done a major harm to scientific and academic activities in Iran and has given way to production of low quality graduates.

\section{Conclusions}

Under Neoliberalism, universities transform to corporations based on the free market principles. In these universities professors and managers (as producers) produce knowledge and academic courses (as commodities) and try to sell them to the customers (students and industries) in the competitive markets. In these corporative universities all relations and policies are based on market-oriented management. Coercive accountability; transparency; emphasis on the objective outputs; unequal power relations, and engineering attitude toward education are some of the characteristic features of corporative universities. Giroux believes Neoliberalism tries to employ HE in order to legitimize its form of governmentality that is based on possessive individualism and unequal power relations.

In Iran we also witness the market-oriented reforms in HE, seeking to marketize university and turning knowledge into a salable commodity. It should be noted that what is going on in Iranian universities, is using the logic of Neoliberalism to justify the profit-driven attitude toward the knowledge and university, which leads to an irrational form of privatization and commercialization of higher education. This phantom of Neoliberalism has caused an increase in the number of private universities with poor qualities; the emergence of the market for articles and theses; promotion and expansion of the Science and Technology Parks even for Arts and Humanities, and finally has brought about a profit-driven attitude toward knowledge and academic research. Perhaps all of these problems are not created by Neoliberalism, but no doubt the logic of Neoliberalism has a significant role in justifying this form of market-driven reforms.

In recent years scientific and academic plans and policies in Iran are trying to promote privatization and commercialization as a necessary basis of the political and economic power, but it should be noted that these reforms are not in accord with religious foundations rather they undermine the role of Humanities as the basis for establishment of the Islamic civilization. Some researches throughout the world believe that privatization, market-oriented management and national standard tests are undermining social justice and participatory democracy and legitimize inequalities and will lead to uprisings. Thus, current process of commercialization and privatization of HE in Iran not only is incompatible with Islamic education, but also functions as an obstacle on the way of identification and realization of the goals of Islamic education.

\section{References}

Ambrosio, J. (2013). Changing the subject: Neoliberalism and accountability in public education. Educational Studies. Journal of the American Educational Studies Association, 49 (4), 316-333.

Aronowitz, S., \& Giroux, H. (2000). The corporate university and the politics of education. The Educational Forum, 64 (4), 332 -339.

Bagheri, A., Karimof, M. (2013). Critical analysis of the history of higher education in Iran. Cultural Sociology, 4 (1), 23-57 (In Persian). 
Brown, B. (2011). The march of market. In M. Molesworth, R. Scullion \& E. Nixon (Eds.), The marketization of higher education and the student as consumer (11-25). New York: Routledge Taylor and Francis Group.

Buchanan, J. (1984). Politic without Romance: A sketch of positive public choice and its normative implications. In J. Buchanan \& R. Tollison (Eds.), The theory of public choice (pp. 11-23). The University of Michigan Press.

Connell, R. (2013). The neoliberal cascade and education: An essay on the market agenda and its consequences. Critical Studies in Education, 54 (2), 99-112.

Davies, B., \& Bansel, P. (2007). Neoliberalism and education. International Journal of Qualitative Studies in Education, 20 (3), 247-259.

Foskett, N. (2011). Markets, government, funding and the Marketization of UK higher education. In M. Molesworth, R. Scullion \& E. Nixon (Eds.), The marketization of higher education and the student as consumer (pp. 25-39). New York: Routledge Taylor and Francis Group.

Furedi, F. (2011). Introduction to the Marketization of higher education and the student as consumer. In M. Molesworth, R. Scullion \& E. Nixon (Eds), The marketization of higher education and the student as consumer. New York: Routledge Taylor and Francis Group.

Giroux, H. (1999). Schools for sale: Public education, corporate culture and citizen-consumer. Educational Forum, 63 (2), 140-149.

Giroux, H. (2003). Racial injustice and disposable youth in the age of zero tolerance. International Journal of Qualitative Studies in Education, 16 (4), 553 -565.

Giroux, H. (2009). Youth in suspect society: Democracy or disposability? McMillian Palgrave.

Harvey, D. (2005). A brief history of neo- liberalism. London: Oxford University Press.

Hall, S. (2012). The neo-liberal revolution. In J. Rutherford \& S. Davison (Eds.), The neoliberal crisis (pp. 8-27). Sounding Press.

Khaki, G. N., Bhat, M. A. (2015). Pahlavi's the pioneer of education in Iran: A study of Reza Shah. International Journal of Education (IJE), 3 (2), 45-51.

Iranian Islamic Parliament Research Center. (2010). Fifth plans of development of I. R. Iran (2011-2016). Retrieved from http://rc.majlis.ir/fa/law/show/790196.

Official Website of the Government of I. R. Iran. (2016). Sixth plans of development of I. R. Iran. Retrieved from http://dolat.ir/detail/281959.

Ministry of the Science, Research and Technology of the Iran. (2017). Universities and higher education institutions in Iran. Retrieved from www.msrt.ir/fa/45.

Olssen, M., Peters, M. (2005). Neoliberalism, higher education and the knowledge economy: From the free market to knowledge capitalism. Journal of Education Policy, 20 (3) 313-345.

Oplatka, I., Foskett, N., Hemsley-Brown, J. (2002). Educational marketization and the head's psychological well-being: A speculative conceptualization. British Journal of Educational Studies, 50 (4), 419-441.

Rowlands, J., Rawolle, S. (2013). Neoliberalism is not a theory of everything: A Bourdieuian analysis of illusion in educational research. Critical Studies in Education, 54 (3), 260-272.

Saad-Filho, A., \& Johnston, D. (2005). Introduction. In A. Saad- Filho \& D. Johnston (Eds.), Neoliberalism: A critical reader. London: Pluto Press.

Stone, R. (2016). A shady market in scientific papers mars Iran's rise in science. Sciencemag. DOI: 10.1126/science.aah7297.

Supreme Council of Cultural Revolution of Iran. (2010). Documents of comprehensive scientific map of Iran. Retrieved from http://sccr.ir/pages/.

Turner, R. (2008). Neoliberalism: History, concept and policies. Edinburg University Press. 
Mohammad Hasan MIRZAMOHAMMADI, Hamdollah MOHAMMADI. Neoliberalism and higher education in Iran: A critical perspective PROBLEMS

OF EDUCATION

IN THE $21^{\text {st }}$ CENTURY

Vol. 75, No. 5, 2017

482

Received: August 28, 2017

Accepted: October 18, 2017

Mohammad Hasan

Mirzamohammadi
$\mathrm{PhD}$, Associate Professor in Philosophy of Education, Shahed

University, Tehran, Iran.

E-mail: mir.educated@gmail.com

Ph.D Candidate in Philosophy of Education, Tehran University, Tehran, Iran.

E-mail: H9mohammadi@yahoo.com 